\title{
Management of community acquired pneumonia (CAP) in children: Clinical practice guidelines by the Paediatrics Association of Nigeria (PAN)
}

\author{
${ }^{1}$ Olowu A, ${ }^{2}$ Elusiyan JBE, ${ }^{3}$ Esangbedo D, ${ }^{4}$ Ekure EN, ${ }^{4}$ Esezobor C, ${ }^{5}$ Falade AG \\ ${ }^{5}$ Osinusi K, ${ }^{6}$ Mukhtar-Yola M, ${ }^{7}$ Meremikwu M, ${ }^{8}$ Ibe B, ${ }^{9}$ Johnson WBR \\ ${ }^{10}$ Oviawe O, ${ }^{11}$ Bastos I
}

\begin{abstract}
${ }^{1}$ Department of Paediatrics, Ogun State Uuniversity, Ago-iwoye, ${ }^{2}$ Department of Paediatrics and Child Health, Obafemi Awolowo University, Ile-Ife, Osun-State, ${ }^{3}$ Providence Hospital, Lagos, Nigeria, ${ }^{4}$ Department of Paediatrics, Lagos University Teaching Hospital, Lagos, ${ }^{5}$ Department of Paediatrics, University College Hospital, Ibadan, ${ }^{6}$ Department of Paediatrics, National Hospital, Abuja, ${ }^{7}$ Department of Paediatrics, University of Calabar, Calabar, ${ }^{8}$ Department of Paediatrics, University of Nigeria Teaching Hospital, Enugu, ${ }^{9}$ Department of Paediatrics, University of Ilorin, Ilorin, ${ }^{10}$ Department of Paediatrics, University of Benin, Benin City, ${ }^{11}$ Nursing services, Lagos University Teaching Hospital, Lagos,
\end{abstract}

DOI:http://dx.doi.org/10.4314/njp.v42i4.1

Accepted: 4th June 2015

Preamble

Against the background of the subsisting high childhood mortality indices in Nigeria, vis-a-vis the global efforts in the last 10 years to stem the tide (as articulated in the Millennium Development Goals), there has been a corresponding need to address the common causes of deaths in under- fives. In Nigeria, as is the case in many countries in

\section{Definition}

Pneumonia is the inflammation of lung parenchyma due to pathogenic micro-organisms such as bacteria, viruses and fungi. Clinically, it is also defined as a condition typically associated with fever, respiratory symptoms, and evidence of parenchymal involvement, either by physical examination or the presence of infiltrates on chest radiograph. In order to facilitate early recognition, prompt treatment and referral of children with pneumonia, the World Health Organization (WHO) definition of pneumonia relies on simple clinical signs, such as tachypnoea and lower chest in-drawing (Table 1). According to this definition, severity classification of pneumonia in under-fives is non-severe and severe (Table 1).

\section{Classification of pneumonia}

Pneumonia can be classified using several parameters:

a. Source of infection: Community-acquired pneumonia (CAP) and hospital acquired infection (nosocomial) pneumonia. CAP is defined as pneumonia in a previously healthy child who acquired the infection outside a health facility or develops the illness within 48 hours of admission into a health population) has become imperative. This was the logic that informed the current initiative of the Paediatric Association of Nigeria, aimed at formulating diagnostic, treatment and control policies with respect to paediatric community acquired pneumonia (CAP). This document is targeted primarily at health care providers working in Nigeria in centres with limited facilities as well as those working in tertiary hospitals. facility.

b. Duration of Pneumonia: Pneumonia can be classified as "acute" (less than two weeks duration) and "chronic". Chronic pneumonias tend to be either mycobacterial or fungal. A microbiological classification involves knowledge of the aetiological agents.

c. Anatomical area(s) of involvement: Usually recognized based on chest radiographic parameters:

d. Lobar pneumonia: characterized by the presence of a smooth, dense homogenous opacity of a single lobe, or a segment of a lobe, of a lung. The aetiological agent is often Streptococcus pneumoniae. Multilobar pneumonia involves more than one lobe, often causing a more severe illness.

e. Bronchopneumonia: there are patchy changes in the lung around the bronchi or bronchioles.

f. Interstitial pneumonia: this involves the areas in between the alveoli. It is more likely to be caused by viruses or by atypical bacteria

g. Microbiologial classification: This is based on the organism isolated/identified. This is exemplified by viral, bacterial, fungal, mycoplasmal and chlamydial pneumonia. 


\section{Epidemiology}

Pneumonia is the leading cause of death in children under five years around the world, accounting for $~ 20 \%$ of all under-five mortality globally. Indeed, more than 155 million new episodes of clinical pneumonia occur in children under 5 years of age annually with about $10 \%$ of these being of sufficient severity to be life-threatening requiring hospitalization. In 2011, for example, an estimated 1.3 million children under five years died from pneumonia. Nigeria ranked fifth among the countries with the highest absolute number of new cases of clinical pneumonia in 2008 with an estimated 6.1 million new cases. By 2010, the estimated number of underfive children dying from pneumonia in Nigeria was more than 120,000, a disease burden that constitutes the highest in Africa. The burden of disease is mainly in the younger age groups. Furthermore, while $81 \%$ of deaths from pneumonia happen in children younger than 2 years, disease incidence has been shown to fall less rapidly with age than does mortality from the disease. Also, the global pneumonia incidence shows a higher prevalence among boys than girls with the largest differences recorded in South Asia regions. Indeed the recent series by Abdulkarim in Ilorin reported a male to female ratio of $1.5: 1$.

\section{Aetiological Agents}

The aetiological agents of CAP could be divided into bacterial, viral and fungal.

\section{a. Bacteria}

Common bacterial agents

Streptococcus pneumoniae

Haemophilus influenzae

Staphylococcus aureus

\section{Less common bacterial agents}

Klebsiella pneumoniae

Mycoplasma pneumoniae

Chlamydophilia pneumoniae

Non-typhoidal salmonella

Non-typeable Haemophilus influenza

\section{b. Viruses}

Common Viral agents

Respiratory syncytial virus (RSV)

Influenza A \& B virus

Parainfluenza

Less common viral agents

Adenovirus (ADV)

Human metapneumovirus

Measles virus

\section{c. Others}

Mycobacterium spp

Pneumocystis jiroveci

Globally, the common pathogens of CAP and the corresponding paediatric population are:

\section{General population of children}

The two commonest bacteria are Streptococcus pneumoniae (30-50\% of pneumonia cases) and $H$. influenzae type $b$ (Hib; $10-30 \%$ of cases), and the main viral cause is RSV, but estimates of their relative importance vary in different settings.

\section{HIV-infected children}

Pneumocystis jiroveci and Mycobacterium tuberculosis areimportant causes of pneumonia, though bacterial causes remain the major cause of pneumonia mortality.

\section{Severely malnourished children}

Klebsiella pneumoniae, S. aureus, S. pneumoniae, E. coli, and $H$. influenzaeare the major aetiological agents with very few data on the role of respiratory viruses and M.tuberculosis.

\section{Neonates}

The organisms responsible for pneumonia in this age group are essentially similar to those causing neonatal sepsis and include gram-negative enteric organisms such as E.. coli, Klebsiella spp, and gram-positive organisms, mainly S. pneumoniae, S. aureus and group B Streptococcus.

\section{School-aged children}

Mycoplasma pneumoniae is an important cause of pneumonia in school-aged children.

However, in Nigeria pathogens causing CAP in the under-fives are as shown in the table below:

Table 1: Aetiological agents of childhood pneumonia in Nigeria

Studies Isolated organisms

Abdulkarim et al2013

Staphylococcus aureus (23.9\%), Klebsiellaspp (17.4\%), coliforms and coagulase negative Staphylococcus( $15.2 \%)$ each; micrococcus and non-haemolytic Streptococcus $(6.5 \%)$ each

Falade et al 2009 S. pneumoniae (9), Hib (2), and others- Klebsiellaspp (14 cases), Salmonella spp (11), Pseudomonas. aeruginosa (6), Enterococcus. faecalis (2), E. coli (2), and possible S. aureus (44) but only 1 of the 44 isolates was confirmed

Johnson et al 2008

Bacteria:S. aureus (37.3\%), Klebsiella spp. $(15.3 \%)$ and $S$. pneumoniae $(5.1 \%) .92$ viruses: RSV (30.4\%), PIV-3 (19.5\%) Flu-A (17.3\%)

Tagbo et al2005 S.pneumoniae (3), S. aureus (2), coliforms (2), H. influenzae (1), Proteus mirabilis (1), P. aeruginosa (1)

Results of aetiology of pneumonia studies in Nigeria are at variance with the global trend due to a) high pre-consultation antibiotic use; b) use of human blood to prepare blood agar; and c) lack of current method to distinguish coagulase negative Staphylococcus from $S$. aureus. 
Predisposing/Risk Factors

Risk factors for CAP include the following:

\begin{tabular}{|c|c|c|c|}
\hline $\begin{array}{l}\text { Definite Risk } \\
\text { Factors } \\
\end{array}$ & $\begin{array}{l}\text { Likely Risk } \\
\text { Factors }\end{array}$ & $\begin{array}{l}\text { Possible Risk } \\
\text { Factors }\end{array}$ & $\begin{array}{l}\text { Risk Factors } \\
\text { for neonate }\end{array}$ \\
\hline $\begin{array}{l}\text { Malnutrition } \\
\text { (WAZ score <- } \\
\text { 2) }\end{array}$ & Parental smoking & $\begin{array}{l}\text { Mother's } \\
\text { education }\end{array}$ & $\begin{array}{l}\text { Premature } \\
\text { rupture of } \\
\text { membranes }\end{array}$ \\
\hline $\begin{array}{l}\text { Low birth } \\
\text { weight }\end{array}$ & Zinc deficiency & $\begin{array}{l}\text { Day care } \\
\text { attendance }\end{array}$ & $\begin{array}{l}\text { Low birth } \\
\text { weight }\end{array}$ \\
\hline $\begin{array}{l}\text { Non-exclusive } \\
\text { breastfeeding }\end{array}$ & $\begin{array}{l}\text { Mother's experi- } \\
\text { ence as a care- } \\
\text { giver }\end{array}$ & $\begin{array}{l}\text { Outdoor air } \\
\text { pollution }\end{array}$ & $\begin{array}{l}\text { Preterm deliv- } \\
\text { ery }\end{array}$ \\
\hline $\begin{array}{l}\text { Lack of mea- } \\
\text { sles immuniza- } \\
\text { tion } \\
\text { Household air } \\
\text { pollution } \\
\text { Overcrowding }\end{array}$ & $\begin{array}{l}\text { Concomitant } \\
\text { disease, e.g. } \\
\text { heart disease, } \\
\text { sickle cell dis- } \\
\text { ease, immunode- } \\
\text { ficiency states }\end{array}$ & & $\begin{array}{l}\text { Lack of exclu- } \\
\text { sive breast- } \\
\text { feeding } \\
\text { Concomitant } \\
\text { disease, e.g. } \\
\text { heart disease }\end{array}$ \\
\hline
\end{tabular}

\section{Pathophysiology and Pathogenesis of Pneumonia}

The respiratory tract is replete with both specific and non-specific protective mechanisms which act in concert to keep the airways and alveoli free of both particulate materials and microbes.

The non-specific defense mechanisms include the nasal hair and nasal turbinates, the vocal cord, glottis, mucociliary clearance and the cough reflex. Others include humidification, neutrophils, resident alveolar macrophages, airway secretions including lysozymes, iron binding proteins, complements and surfactant.

The specific defense system involves the coordinated activities of $\mathrm{B}$ and $\mathrm{T}$ lymphocytes resulting in activation of cytotoxic $\mathrm{T}$ cells and specific antibodies

Microbes are introduced to the airway via inhalational or haematogenous route. When microbes evade the nonspecific defense system they provoke an inflammatory response leading to exudates of plasma, neutrophils, lymphocytes, macrophages and inflammatory debris.

The inflammatory debris narrows the airway and increases airway resistance. The debris also causes partial or total occlusion of the smaller airways with resultant atelectasis and hyperinflation of some alveoli leading to increased work of breathing and wheezing. Furthermore, the increased alveolar diffusion barrier causes significant ventilation-perfusion mismatch and intrapulmonary shunt.

These pathophysiological events are responsible for (1) tachypnoea (2) increased work of breathing (3) crepitations (4) reduced air entry (5) dull percussion note (6) wheeze/rhonchi and (7) fever

Seeding of bacteria to the blood and other organs could also occur causing organ-specific manifestations, (such as meningitis, septic arthritis, acute ostemyelitis), while the inevitable increase in pulmonary vascular resistance coupled with increased myocardial oxygen requirement may cause heart failure.

\section{Clinical Features}

The main objective of the initial clinical assessment is to decide if the child's history and physical examination findings are suggestive of CAP.

\section{Clinical Assessment}

1. Relevant history questions:

- Host-related factors: Age, immunization status, lack of exclusive breastfeeding, low birth weight, severe malnutrition

- Environmental Factors: household air pollution e.g. firewood burning, passive tobacco smoking, season of the year, overcrowding and poor ventilation

- Co-morbidities: heart disease, sickle cell disease, HIV infection, gastro-esophageal reflux disease

2. An initial physical examination should be performed for signs of respiratory illness and for fever. These signs include tachypnoea, evidence of increased work of breathing, cyanosis, auscultatory signs such as decreased breath sounds, crepitations and bronchial breath sounds. Other features to be looked for include evidence of other organ involvement such as heart failure (tachycardia, tender hepatomegaly), acute osteomyelitis, septic arthritis and meningitis

The following points should be noted, however:

1. Respiratory rates are best determined over a full 60second period and inconsistencies require repeated observations. This is required in view of the effects of the peculiar behavioral and physiologic factors in children.

2. No single clinical finding is sufficient in determining the presence or absence of pneumonia; combinations of clinical findings are more useful.

3. The best individual examination measures in children less than 5 years are:nasal flaring (age $<12$ months); oxygen saturation $90 \%$ or less in room air; tachypnoea; and retractions. The absence of tachypnoea alone or of all other signs of respiratory illness is highly suggestive of the absence of pneumonia.

4. Among children less than 5 years, especially in neonates and those with severe malnutrition pneumonia may be present without signs of respiratory illness.

\begin{tabular}{|c|c|c|}
\hline \multicolumn{3}{|c|}{$\begin{array}{l}\text { Table 3: Respiratory Rate Cut-offs for Children According to } \\
\text { Age Groups }\end{array}$} \\
\hline Age groups & $\begin{array}{l}\text { Approximate normal } \\
\text { respiratory rates } \\
\text { (bpm) }\end{array}$ & $\begin{array}{l}\text { Tachypnoea } \\
\text { threshold (bpm) }\end{array}$ \\
\hline Less than 2 months & 40 to 60 & 260 \\
\hline 2 up to 12 months & 25 to 40 & $\geq 50$ \\
\hline 1 up to 5 years & 20 to 30 & $\geq 40$ \\
\hline$\geq 5$ years & 15 to 25 & 230 \\
\hline
\end{tabular}

\section{Classification of severity of pneumonia}

Children with pneumonia usually present with cough and/ or difficult breathing, fast breathing and fever. These children may either have severe or non-severe pneumonia, as defined below. This classification forms the basis of subsequent management: 


\section{a. Pneumonia (non-severe)}

- Mild chest indrawing: (i.e. lower chest wall goes in when the child breathes in)

- chest auscultation signs: decreased breath sounds, bronchial breath sounds, crackles or crepitations

\section{b. Severe pneumonia}

These children will have, in addition to the features of non-severe pneumonia, at least one or more of the following:

- Central cyanosis, or oxygen saturation $90 \%$ or less on pulse oximetry in room air

- Severe respiratory distress (e.g. grunting, very severe chest indrawing)

- chest auscultatory signs: decreased/absent breath sounds or vocal resonance as in pleural effusion, pleural rub

- Signs of pneumonia with a general danger sign: Inability to breastfeed or drink, lethargy or unconscious, convulsions.

- Presence of complications or co-morbidities: e.g. congestive heart failure, severe malnutrition and sickle cell disease

Clinical chest examination is useful in providing anatomical diagnosis (Table 4):

\begin{tabular}{lll}
\hline \multicolumn{2}{l}{ Table 4: Chest Signs of Lobar and Bronchopneumonia } \\
Signs & Lobar pneumonia & $\begin{array}{l}\text { Broncho- } \\
\text { pneumonia }\end{array}$ \\
\hline Chest deformity & None & None \\
Chest movement & Diminished or absent & Normal \\
Mediastinal shift & None & None \\
Vocal fremitus & Increased & Normal \\
Percussion note & Dull & Resonant \\
Breath sound & Bronchial or vesicular & Vesicular \\
Added sound & Crepitations (crackles) & $\begin{array}{l}\text { Crepitations } \\
\text { (crackles) }\end{array}$ \\
Vocal resonance & Increased & Normal \\
\hline
\end{tabular}

\section{Diagnostic Evaluation}

Management of CAP can be in a community or hospital settings. Community setting includes: the home, health centres, community pharmacy shops/stores; as against hospital setting, i.e. emergency departments, out-patient and in-patient departments.. Emphasis on community setting is on treatment of symptoms and prevention of progression to severe cases of pneumonia in order to avoid hospitalization.

For a child with suspected CAP in the community, there are no indicators for any general investigations. Investigation of any sort is not necessary and where this has been done, it has not contributed to outcome of management. We recommend instruction on respiratory rate count for mothers, pharmacy assistants and community health workers as part of capacity building for recognition of varying severity of the disease and appropriate referral option. Also recommended is the knowledge of the haemoglobin genotype of the child.

At hospital setting, aims of management include aetiological diagnosis, anatomical/pathological diagnosis and determination/correction of effects of the CAP on the child.

\section{Supportive Investigations}

- Anthropometry - weight, height, mid upper arm circumference

- Bedside determination of respiratory rate and pulse rate

- Pulse oximetry for oxygen saturation: Helpful in monitoring response to therapy and detection of cyanosis. Acceptable cut-off value for discontinuing oxygen therapy is is $\mathrm{SPO}_{2} 90 \%$ or more.

- Acute phase reactants (APR), C-reactive protein (CRP), erythrocyte sedimentation rate (ESR), procalcitonin (PCT). While these non-specific inflammatory markers may be of clinical benefit, their usefulness in differentiating the cause or indeed the severity of the CAP is doubtful.

\section{Diagnostic Imaging}

Diagnosis of CAP is commonly achieved by carefully considering the symptoms and signs, and in the majority of cases, further investigations are uncalled for, especially in resource-poor countries.

Plain chest radiograph is the commonest ancillary investigation for confirmation of CAP. Its main value is the identification of opacities in the chest radiograph. Indications for chest radiograph in CAP include:

a. Presence of significant chest retractions

b. Failure to respond to initial course of antibiotic therapy at 48 hours

c. Suspected CAP with complications, e.g. pleural effusion, pneumothorax

d. Progressive symptoms despite antibiotic therapy

In general CAP requiring hospitalization is an indication for requesting a chest radiograph. There is controversy regarding the timing and the specific views of the chest radiograph required. The majority of clinicians favour chest radiograph for severe pneumonia at presentation, while others favour chest radiograph as a pre-discharge recommendation. Follow-up chest radiographs are unnecessary in children who recover uneventfully from CAP. Commonly, anteroposterior (AP) view is all that is required. In the Nigeria situation, simultaneous AP and lateral views are preferred in order to assess additionally the hilum, paratracheal and paravertebral structures. Where massive effusion is suspected, lateral views should also be obtained following a substantial drainage of the effusion.

Possible chest radiograph findings indicative of CAP include: lobar infiltrates, interstitial infiltrates (bacterial, 
viral, atypical pneumonia), lobar consolidation, atelectasis, nodular infiltration, hilar adenopathy, pneumatocoeles, etc.

However, the 'gold standard' for the diagnosis of pneumonia is chest radiography. Nevertheless, some of the limitations of chest radiography include:

1. Interpretation of the chest radiographs in pneumonia varies as some studies classify only cases with alveolar consolidation as pneumonia, others include the presence of any pulmonary parenchymal infiltrates

2. Poor agreement between radiologists on the presence or absence of infiltrates in paediatric chest radiographs even when standard reporting formats are used.

3. Chest radiographs predict the post-mortem diagnosis of pneumonia in severely malnourished children with $100 \%$ specificity but only $50 \%$ sensitivity.

4. Facility for chest radiography is not available in most health facilities in developing countries

There is no sufficient evidence to recommend the routine use of ultrasound and computerized tomography scan in CAP.

\section{Isolation of Microbiologic Agents}

This is a desirable investigation in children with CAP in order to avoid antibiotics misuse and development of bacterial resistance. Available methods include blood culture, pleural fluid culture, nasopharyngeal culture, sputum (induced using 5\% normal saline) culture, etc. However, the gold standard for sample recovery is lung puncture aspirate from infected region of the lung. Emphasis should be on the less invasive sampling methods Although new molecular diagnostic tests are available, e.g., polymerase chain reaction (PCR), their usefulness in our hospital setting is limited.

\section{Recommendations for Management of Community Acquired Pneumonia Introduction}

Results of aetiological studies of CAP in Nigeria, as well as its complications are essential to formulate its management. It is paramount to consider the management as first/alternative and second lines, which will fit into management at primary, secondary and tertiary levels.

A stepwise approach to management is preferred: In children with a history of fever, cough, and/or difficult breathing:

Step 1: Count the respiratory rate for one full minute when the child is awake and calm, or asleep. If the breathing is fast, consider pneumonia.

Step 2: Look for evidence of increased work of breathing (difficult breathing): in-drawing of the lower chest wall when the child breathes in and nasal flaring

Step 3: Check for cyanosis (bluish discolouration) by looking at the tongue and buccal mucosa. Document the oxygen saturation using a pulse oximeter.
Step 4: Palpate for the position of the trachea

Step 5: Percuss the chest for dullness, or hyperresonance

Step 6: Auscultate for bronchial breath sounds, crepitations or rhonchi.

Step 7: Look for complications such as heart failure (tachycardia, tender hepatomegaly), pleural effusion (stony dull percussion note, reduced/absent breath sound over the region of either or both chest regions), pneumothorax (hyper-resonance and reduced/absent breath sound over the upper and lateral region of the involved lung field).

Step 8: Look for signs of other organ involvement. Ask/ determine if convulsion, lethargy, inability to drink or feed or not responding to calls is present. Presence of these features or any of the complications listed above indicates severe pneumonia.

Step 9: Classify the severity of pneumonia (using WHO classification; see above)

Step 10: Decide on who needs hospitalization. Criteria for management in the hospital are:

- Age less than 2 months

- Severe pneumonia

- $\quad$ Presence of complications or co-morbidities

- $\mathrm{SpO}_{2} 90 \%$ or less in room air.

Step 11: Decide on relevant investigations:

- Chest radiography is NOT required in children with pneumonia to be managed as outpatient

- Do chest radiography in children with pneumonia needing hospitalization, more so in those children suspected of having complications such as parapneumonic effusion (pleural effusion, empyema) or pneumothorax

- $\quad$ Routine full blood count is NOT required for children suspected of having pneumonia to be managed in the outpatient

- A full blood count should be obtained for all children with severe pneumonia or sick enough to be hospitalized.

- Because malaria is a common co-morbidity in this environment, screen for malaria parasite

- Blood culture should be obtained in sick children requiring hospitalization

Serum electrolytes, urea and creatinine, and random blood sugar should be obtained in children with severe pneumonia. 


\begin{tabular}{|c|c|c|c|c|}
\hline \multicolumn{5}{|c|}{ Step 12: Give systemic antibiotics to all children with pneumonia } \\
\hline $\begin{array}{l}\text { Category } \\
\text { of children }\end{array}$ & Outpatients & & Inpatients & \\
\hline \multirow[b]{2}{*}{$<2$ months } & First line & Alternatives ${ }^{*}$ & First line & Alternatives* \\
\hline & \multicolumn{4}{|c|}{ Admit and treat as neonatal sepsis } \\
\hline$\geq 2$ months & $\begin{array}{l}\text { High doseOral } \\
\text { amoxicillin } \\
\text { (90mg/kg/day in } \\
2 \text { divided doses) } \\
\text { for at least } 5 \\
\text { days }\end{array}$ & $\begin{array}{l}\text { Oral amoxicillin-clavulanic } \\
\text { acid (amoxicillin compo- } \\
\text { nent } 90 \mathrm{mg} / \mathrm{kg} / \text { dayin } 2 \text { di- } \\
\text { vided doses) OR oralcefpo- } \\
\text { doxime }(10 \mathrm{mg} / \mathrm{kg} / \text { day in } 2 \\
\text { divided doses) OR oral } \\
\text { cefuroxime }(20-30 \mathrm{mg} / \mathrm{kg} / \\
\text { day in } 2 \text { divided doses) for } \\
\text { at least } 5 \text { days }\end{array}$ & $\begin{array}{l}\text { IV amoxicillin } \\
\text { ( } 150 \mathrm{mg} / \mathrm{kg} / \text { day in } 3 \\
\text { divided doses) AND } \\
\text { IV/IM genticin (5- } \\
7.5 \mathrm{mg} / \mathrm{kg} \text { once } \\
\text { daily) for at least } 5 \\
\text { days }\end{array}$ & $\begin{array}{l}\text { IV ceftriaxone }(50-100 \mathrm{mg} / \mathrm{kg} / \text { day every } \\
12-24 \text { hours), OR } \\
\text { IV cefotaxime }(100-200 \mathrm{mg} / \mathrm{kg} / \text { day in } 4 \\
\text { divided doses), OR } \\
\text { IV/IM genticin }(5-7.5 \mathrm{mg} / \mathrm{kg} \text { once daily) } \\
\text { AND IV cloxacillin }(100-200 \mathrm{mg} / \mathrm{kg} \text { in } 4 \\
\text { divided doses)OR } \\
\text { IV cefuroxime ( } 150 \mathrm{mg} / \mathrm{kg} / \text { day in } 3 \text { di- } \\
\text { vided doses)AND IV/IM genticin }(5- \\
7.5 \mathrm{mg} / \mathrm{kg} \text { once daily) for at least } 5 \text { days. }\end{array}$ \\
\hline $\begin{array}{l}\text { HIV- } \\
\text { infected } \\
\text { children }\end{array}$ & $\begin{array}{l}\text { High doseOral } \\
\text { amoxicillin } \\
\text { ( } 90 \mathrm{mg} / \mathrm{kg} / \text { day in } \\
2 \text { divided doses) } \\
\text { for } 10 \text { days }\end{array}$ & $\begin{array}{l}\text { Oral amoxicillin-clavulanic } \\
\text { acid (amoxicillin compo- } \\
\text { nent } 90 \mathrm{mg} / \mathrm{kg} / \text { dayin } 2 \text { di- } \\
\text { vided doses) OR oralcefpo- } \\
\text { doxime }(10 \mathrm{mg} / \mathrm{kg} / \text { day in } 2 \\
\text { divided doses) OR oral } \\
\text { cefuroxime }(20-30 \mathrm{mg} / \mathrm{kg} / \\
\text { day in } 2 \text { divided doses) for } \\
\text { at least } 10 \text { days }\end{array}$ & $\begin{array}{l}\text { IV amoxicillin } \\
\text { (150mg/kg/day in } 3 \\
\text { divided doses) AND } \\
\text { IV/IM genticin (5- } \\
7.5 \mathrm{mg} / \mathrm{kg} \text { once } \\
\text { daily) PLUS high } \\
\text { dose co-trimoxazole } \\
\text { (20mg/kg/day of } \\
\text { trimethoprim) for at } \\
\text { least } 10 \text { days }\end{array}$ & $\begin{array}{l}\text { IV ceftriaxone }(50-100 \mathrm{mg} / \mathrm{kg} / \text { day every } \\
12-24 \text { hours), OR } \\
\text { IV cefotaxime }(100-200 \mathrm{mg} / \mathrm{kg} / \text { day in } 4 \\
\text { divided doses) OR } \\
\text { IV cefuroxime }(150 \mathrm{mg} / \mathrm{kg} / \text { day in } 3 \text { di- } \\
\text { vided doses)AND IV/IM genticin (5- } \\
7.5 \mathrm{mg} / \mathrm{kg} \text { once daily) } \\
\text { PLUShigh dose co-trimoxazole ( } 20 \mathrm{mg} / \\
\text { kg/day of trimethoprim in } 4 \text { divided } \\
\text { doses)for at least } 10 \text { days }\end{array}$ \\
\hline $\begin{array}{l}\text { Children } \\
\text { with sickle } \\
\text { cell disease }\end{array}$ & $\begin{array}{l}\text { High doseOral } \\
\text { amoxicillin } \\
\text { (90mg/kg/day in } \\
2 \text { divided doses) } \\
\text { for at least } 5 \\
\text { days }\end{array}$ & $\begin{array}{l}\text { Oral amoxicillin-clavulanic } \\
\text { acid (amoxicillin compo- } \\
\text { nent } 90 \mathrm{mg} / \mathrm{kg} / \text { dayin } 2 \text { di- } \\
\text { vided doses) OR oralcefpo- } \\
\text { doxime }(10 \mathrm{mg} / \mathrm{kg} / \text { day in } 2 \\
\text { divided doses) OR oral } \\
\text { cefuroxime }(20-30 \mathrm{mg} / \mathrm{kg} / \\
\text { day in } 2 \text { divided doses) for } \\
\text { at least } 5 \text { days }\end{array}$ & $\begin{array}{l}\text { IV amoxicillin } \\
\text { (150mg/kg/day in } 3 \\
\text { divided doses) AND } \\
\text { IV/IM genticin (5- } \\
7.5 \mathrm{mg} / \mathrm{kg} \text { once } \\
\text { daily) PLUS } \\
\text { oralerythromycin } \\
(60-100 \mathrm{mg} / \mathrm{kg} / \text { day } \\
\text { in } 4 \text { divided doses)) } \\
\text { for at least } 5 \text { days }\end{array}$ & $\begin{array}{l}\text { IV ceftriaxone }(50-100 \mathrm{mg} / \mathrm{kg} / \text { day every } \\
12-24 \text { hours), OR } \\
\text { IV cefotaxime }(100-200 \mathrm{mg} / \mathrm{kg} / \text { day in } 4 \\
\text { divided doses) OR } \\
\text { IV cefuroxime }(150 \mathrm{mg} / \mathrm{kg} / \text { day in } 3 \text { di- } \\
\text { vided doses) AND IV/IM genticin }(5- \\
7.5 \mathrm{mg} / \mathrm{kg} \text { once daily) for at least } 5 \text { days } \\
\text { PLUS oral azithromycin ( } 10 \mathrm{mg} / \mathrm{kg}) \\
\text { daily dose for } 3 \text { days }\end{array}$ \\
\hline
\end{tabular}

Notes:

Step down to appropriate oral antibiotics when improvement is sustained. For instance, cefpodoxime after ceftriaxone; Target pathogens in outpatients' treatment are S. pneumoniae and Hib; whereas in cases on admission, these as well as $S$. aureus and other bacilli are included; Maximum dose of gentamicin should not exceed 120mg; Chloramphenicol is not included in the antibiotic protocol because of its toxicity in the face of effective alternative antibiotics;

*Alternatives: Consider alternatives when first line drugs are not available or applicable or child has not responded to the first line drugs

\section{Other Supportive Measures}

- Clear the airway using gentle suction as needed, always mouth before nose

- Give supplemental oxygen if oxygen saturation is $90 \%$ or less, in room air or signs of severe respiratory distress are present. If pulse oximetry is not available give oxygen if signs of respiratory distress and or cyanosis are present.

- Give oxygen via nasal prongs or nasal catheters: 0.5 $-1 \mathrm{~L} / \mathrm{min}$ for children $0-2$ months, $2-3 \mathrm{~L} / \mathrm{min}$ for children 3 months to 5 years; maximum of $4 \mathrm{~L} / \mathrm{min}$ for older children)

- Allow small frequent feeds/fluids if tolerated; feeding may also be done using appropriate size nasogastric tube

- If feeds are not tolerated give intravenous isotonic fluid. Ensure it contains at least $5 \%$ glucose (e.g. $5 \%$ dextrose in $0.9 \%$ saline or ringer's lactate with added glucose)

- $\quad$ For high grade fever (temperature $239^{\circ} \mathrm{C}$ ), give paracetamol $10-15 \mathrm{mg} / \mathrm{kg}$ 4-6 hourly, and ibuprofen if required.

- If widespread rhonchi is present (high-pitch continuous sound during expiration only or during both phases of respiration) give first dose of short acting bronchodilator such as salbutamol or albuterol and re-assess

- Nursing care should be provided at least every 3 hours: check vital signs including oxygen saturation

- The doctor should review the child at least twice daily 
When to Consider Referring a Child with Pneumonia to a Tertiary Centre/Getting a Specialist's Review

- If child's clinical state does not improve after 48 hours or worsens within this period

- When the child requires mechanical ventilation at presentation

- If oxygen saturation is persistently $<90 \%$ despite supplemental oxygen

- If blood pressure remains low If the child has altered mental status

When to consider transfers to a Critical Care Unit

- When the child requires mechanical ventilation

- If blood pressure remains low or child requires inotropic agent(s) to maintain normal blood pressure

- If the child has altered mental status

- If oxygen saturation is persistently $<90 \%$ despite supplemental oxygen

- Presence of other organ failure

When to Consider Discharge

- When clinical features such as fast breathing, respiratory distress and fever have resolved for at least 24 hours

- Child is feeding by mouth and tolerates oral medications and

- Caregiver is comfortable about discharge from hospital and capable of administering oral medication (s) if any

\section{At Discharge}

- Plan to review the child two days after discharge

- Review immunization record and make plans to get the child fully immunized if vaccines have been missed. In addition, children under 2 years should get recommended doses of pneumococcal conjugate vaccines (PCV) or $H$. influenzae Type $\mathrm{b}$ conjugate vaccines(Hib vaccine) if not already immunized

- Instruct caregiver to bring child to the hospital when child with cough and catarrh develops fast breathing

- Instruct caregiver to increase frequency of feeding for the next 2 weeks after treatment for pneumonia. Children with moderate to severe malnutrition should receive treatment advice according to standard guidelines

\section{Drugs to Avoid in the Management of Pneumonia}

Cough syrups containing antihistamines or opioids such as codeine, hydrocodeine, because they add little to the management of pneumonia and may be toxic in some children

\section{Counselling/Health Education For CAP}

Health education and guidance play important roles in the management of children with CAP. Counselling should be ongoing from admission to discharge with family regularly updated on progress of management. Information on what the caregiver should observe in the child and report to the health facility should be communicated.

The education should include:

1. The fact that CAP is caused by micro-organisms.

2. Environmental factors that predispose to CAP and CAP-related deaths such as indoor air pollution including passive parental smoking, overcrowding, poor ventilation, poor personal and environmental hygiene. Good hand washing practices should be emphasized.

3. Education about the presenting features with emphasis on the need for early recognition of fast breathing.

4. Immunization against the childhood diseases. Vaccines that protect against pneumonia such as Pneumococcal conjugate vaccine (PCV), Haemophilus influenzae type B vaccine (Hib), pertussis, and measles vaccines should be communicated.

5. The importance of Exclusive breastfeeding in the first 6 months of life and adequate nutrition should be explained to the caregiver.

6. Opportunities should be given for the caregivers to express his/her fears, so that cultural and religious beliefs that are detrimental to achieving optimal health and development of the child should be discussed.

7. The need to avoid self-medications including the use of cough mixtures

\section{Prevention}

There are proven strategies for the prevention of community acquired pneumonia in children. These include:

\section{Specific Vaccines}

Conjugate vaccine for S. pneumoniae

Conjugate vaccine for $\mathrm{H}$. influenzae type $\mathrm{b}$

Influenza vaccine

\section{Other vaccines}

Measles containing vaccine (including booster doses)

BCG vaccine

Pertussis vaccine (now in pentavalent vaccine used nationwide; including booster doses)

\section{Measures to reduce risk factors}

Improved housing: improved ventilation, reduce overcrowding and indoor air pollution

Improved nutrition

Exclusive breastfeeding for the first 6 months

Micronutrients supplementation, including vitamin A and zinc

HIV prevention - prevention of mother-to-child transmission of HIV 
Future Research

Paucity or absence of recent data on various aspects of childhood community acquired pneumonia in Nigeria makes it imperative for research strategies directed at filling the knowledge gaps in:

1. Viral contribution to aetiology of CAP

2. Bacterial super-imposition following an initial viral infection

3. Seasonal variations in the contribution of various organisms to childhood community acquired pneumonia

4. Contribution of Mycoplasma pneumoniae to childhood community acquired pneumonia

5. Severity grading of childhood community acquired pneumonia

6. Antibiotic resistance/sensitivity pattern of common organisms causing community acquired pneumonia

7. Appropriate and relevant clinical scoring tool for pneumonia

8. Usefulness of procalcitonin and C-reactive protein in the diagnosis of CAP

9. Surveillance study on the prevalent pneumococcal serotypes in CAP

10. Surveillance study on the prevalence and the role of non-typeable Haemophilus influenzae in CAP
Appendices

Appendix I: Lung Sound Nomenclature

Lung Sound Nomenclature Description Term

Discontinu- Fine (high pitched, low Fine crackles

ous amplitude, short dura- (crepitations/Rhales) tion)

Coarse crackles

(crepitations/Rhales)

Coarse(low pitched, high amplitude, long duration)

Coarse crackles

(crepitations/Rhales)

Continuous Continuous, musical Rhonchi sound heard during expiration only or during both phases of respiration

NB: Wheezes and Rhonchi may be heard in severe Pneumonia

Appendix II: Methods of Oxygen Delivery

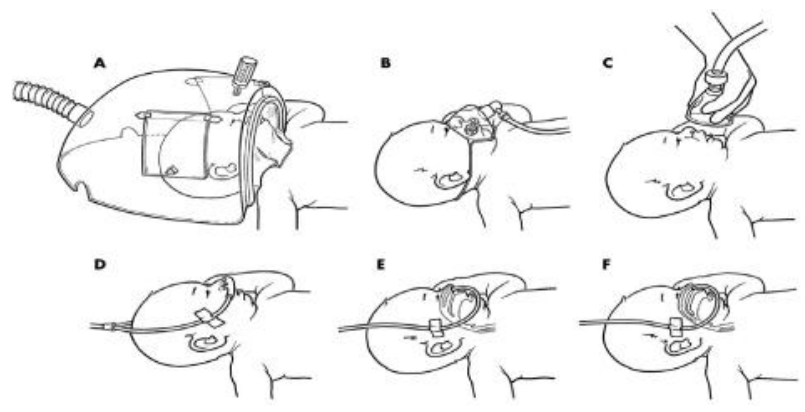

Acknowledgement

We wish to acknowledge the support received from Sanofi and Roche Pharmaceuticals in facilitating the meetings of the drafting committee and for organizing trainings for general practitioners across the country.

\section{References}

1. Bachur R, Perry H, Harper MB. Occult pneumonias: empiric chest radiographs in febrile children with leukocytosis. Annals Emerg Med. 1999;33(2):166-73. Pub Med PMID: 9922412.

2. Berman S, Simoes EA, Lanata C. Respiratory rate and pneumonia in infancy. Arch Dis. Childhood. 1991;66(1):81-4. PubMed PMID: 1994857. Pubmed Central PMCID: 1793190.

3. Black RE, Cousens S, Johnson HL, Lawn JE, Rudan I, Bassani DG, et al. Global, regional, and national causes of child mortality in 2008: a systematic analysis. Lancet. 2010;375(9730):1969-87. PubMed PMID: 20466419.
4. Bradley JS, Byington CL, Shah SS, Alverson B, Carter ER, Harrison $\mathrm{C}$, et al. The management of community-acquired pneumonia in infants and children older than 3 months of age: clinical practice guidelines by the Pediatric Infectious Diseases Society and the Infectious Diseases Society of America. Clin Infect Diseases 2011;53(7):e25-76. PubMed PMID: 21880587.

5. Community Acquired Pneumonia Guideline Team, Cincinnati Children's Hospital Medical Center: Evidence-based care guideline for medical management of Community Acquired Pneumonia in children 60 days to 17 years of age. Guideline 14, pp 1-16, December 22, 2005.
6. Falade AG, Ayede AI. Epidemiology, aetiology and management of childhood acute communityacquired pneumonia in developing countries--a review. Afr J Med Med sc. 2011;40(4):293-308. PubMed PMID: 22783679.

7. Falade AG, Lagunju IA, Bakare RA, Odekanmi AA, Adegbola RA. Invasive pneumococcal disease in children aged $<5$ years admitted to 3 urban hospitals in Ibadan, Nigeria. Clin Infect Disease. 2009 1;48 Suppl 2:S190-6. PubMed PMID: 19191615.

8. Fox B, Bull TB, Guz A. Innervation of alveolar walls in the human lung: an electron microscopic study. J. Anat 1980;131(Pt 4):68392. PubMed PMID: 7216905. Pubmed Central PMCID: 1233220 . 
9. Harari M, Shann F, Spooner V, Meisner S, Carney M, de Campo J. Clinical signs of pneumonia in children. Lancet. 1991 Oct 12;338 (8772):928-30. PubMed PMID: 1681277.

10. Harper SA, Fukuda K, Uyeki TM, Cox NJ, Bridges CB, Advisory Committee on Immunization Practices CDC, et al. Prevention and control of influenza. Recommendations of the Advisory Committee on Immunization Practices (ACIP). MMWR Recommendations and reports : Morbidity and mortality weekly report Recommendations and reports / Centers for Disease Control. $2005 \mathrm{Jul}$ 29;54(RR-8):1-40. PubMed PMID: 16086456.

11. Harris M, Clark J, Coote N, Fletcher P, Harnden A, McKean M, et al. British Thoracic Society guidelines for the management of community acquired pneumonia in children: update 2011. Thorax. 2011 Oct;66 Suppl 2:iil-23. PubMed PMID: 21903691.

12. Izadnegahdar R, Cohen AL, Klugman KP, Qazi SA. Childhood pneumonia in developing countries. Lancet Respiratory Med. 2013 Sep;1(7):574-84. PubMed PMID: 24461618.

13. Johnson WBR AA. Childhood pneumonia in developing countries. Afr J Resp Med. 2013;8(2):49.

14. Johnson AW, Osinusi K, Aderele WI, Gbadero DA, Olaleye OD, Adeyemi-Doro FA. Etiologic agents and outcome determinants of community-acquired pneumonia in urban children: a hospital-based study. J National Med Assoc. 2008;100(4):370-85. PubMed PMID: 18481475.

15. Jona JZ, Belin RP. Basilar pneumonia simulating acute appendicitis in children. Arch Surg. 1976;111(5):552-3. PubMed PMID: 1267602.

16. Juven T, Mertsola J, Waris M, Leinonen M, Meurman O, Roivainen M, et al. Etiology of community-acquired pneumonia in 254 hospitalized children. Ped Infect Disease J. 2000;19(4):2938. PubMed PMID: 10783017.

17. Kim PE, Musher DM, Glezen WP, Rodriguez-Barradas MC, Nahm WK, Wright CE. Association of invasive pneumococcal disease with season, atmospheric conditions, air pollution, and the isolation of respiratory viruses. Clin Infect Diseases. 1996; 22(1):1006. PubMed PMID: 8824973.
18. Leventhal JM. Clinical predictors of pneumonia as a guide to ordering chest roentgenograms. Clinical Pediatrics. 1982;21(12):730-4. PubMed PMID: 7140124.

19. Lodha R, Kabra SK, Pandey RM. Antibiotics for communityacquired pneumonia in children. The Cochrane database of systematic reviews. 2013;6:CD004874. PubMed PMID: 23733365.

20. Mahabee-Gittens EM, GruppPhelan J, Brody AS, Donnelly LF, Bracey SE, Duma EM, et al. Identifying children with pneumonia in the emergency department. Clinical Pediatrics. 2005; 44(5):42735. PubMed PMID: 15965550.

21. Margolis P, Gadomski A. The rational clinical examination. Does this infant have pneumonia? JAMA 1998 28;279(4):308-13. PubMed PMID: 9450716.

22. McIntosh K. Community-acquired pneumonia in children. The New England journal of medicine. 2002 7;346(6):429-37. PubMed PMID: 11832532 .

23. Morley CJ, Thornton AJ, Fowler MA, Cole TJ, Hewson PH. Respiratory rate and severity of illness in babies under 6 months old. Arch Dis. Childhood. 1990; 65(8):8347. PubMed PMID: 2400218. Pubmed Central PMCID: 1792484.

24. Nair H, Simoes EA, Rudan I, Gessner BD, Azziz-Baumgartner E, Zhang JS, et al. Global and regional burden of hospital admissions for severe acute lower respiratory infections in young children in 2010: a systematic analysis. Lancet. 2013: 20;381(9875):138090. PubMed PMID: 23369797. Pubmed Central PMCID: 3986472.

25. Oviawe $\mathrm{O} \mathrm{OH}$. Respiratory rate thresholds in children with varying severity of pneumonia. Int Child Hlth. 1993;4:67-70.

26. Redd SC, Patrick E, Vreuls R, Metsing M, Moteetee M. Comparison of the clinical and radiographic diagnosis of paediatric pneumonia. Trans Royal Soc Trop Med Hyg. 1994;88(3):307-10. PubMed PMID: 7974671.

27. Rudan I, Tomaskovic L, BoschiPinto C, Campbell H, Group WHOCHER. Global estimate of the incidence of clinical pneumonia among children under five years of age. Bulletin WHO 2004; 82(12):895-903. PubMed PMID. 15654403. Pubmed Central PMCID: 2623105.
28. Rudan I, Boschi-Pinto C, Biloglav Z, Mulholland K, Campbell $\mathrm{H}$. Epidemiology and etiology of childhood pneumonia. Bulletin WHO. 2008; 86(5):408-16. PubMed PMID: 18545744. Pubmed Central PMCID: 2647437.

29. Rudan I, Nair H, Marusic A, Campbell H. Reducing mortality from childhood pneumonia and diarrhoea: The leading priority is also the greatest opportunity. $J$. Global Hlth. 2013; 3(1):010101. PubMed PMID: 23826497. Pubmed Central PMCID: 3700027.

30. Rudan I, O'Brien KL, Nair H, Liu L, Theodoratou E, Qazi S, et al. Epidemiology and etiology of childhood pneumonia in 2010: estimates of incidence, severe morbidity, mortality, underlying risk factors and causative pathogens for 192 countries. J. Global Hlth. 2013; 3(1):010401. PubMed PMID: 23826505. Pubmed Central PMCID: 3700032.

31. Singhi S, Dhawan A, Kataria S, Walia BN. Validity of clinical signs for the identification of pneumonia in children. Annal Trop Paediatrics. 1994;14(1):53-8. PubMed PMID: 7516135.

32. Tagbo O, Uchenna O, Anthony H. Childhood parapneumonic pleural effusion in Enugu. Niger Postgraduate Med J. 2005;12(1):2832. PubMed PMID: 15827593.

33. Taylor JA, Del Beccaro M, Done $\mathrm{S}$, Winters W. Establishing clinically relevant standards for tachypnea in febrile children younger than 2 years. Arch Ped. Adolesc Med. 1995;149(3):283-7. PubMed PMID: 7858688.

34. United Nations Children's Fund/ World Health Organization. Pneumonia: The forgotten killer of children. A publication of UNICEF/WHO 2006. Date accessed 09/08/2013.

35. Walker CL, Rudan I, Liu L, Nair $\mathrm{H}$, Theodoratou E, Bhutta ZA, et al. Global burden of childhood pneumonia and diarrhoea. Lancet. 2013: 20;381(9875):1405-16. PubMed PMID: 23582727.

36. World Health Organization pocket book for hospital care for children. Second edition. 2013 
37. Zukin DD, Hoffman JR, Cleveland RH, Kushner DC, Herman TE. Correlation of pulmonary signs and symptoms with chest radiographs in the pediatric age group. Annal Emerg Med. 1986;15 (7):792-6. PubMed PMID: 3729100 .
38. Abdulkarim AA, Ibraheem RM, Adegboye AO, Johnson WBR, Adeboye MAN. Childhood pneumonia at the University of Ilorin Teaching Hospital, Ilorin Nigeria. Niger. J. Paed 2013; 40(3): 284289 